\title{
University Textbooks of Theology: Lexical Features in Relation to Academic Theological Papers
}

\author{
Ivana Knežević \\ University of Belgrade, Faculty of Orthodox Theology, Department of Languages \\ (Универзитет у Београду, Православни богословски факултет, Катедра за језике), Serbia \\ ORCID 0000-0002-5170-2614 \\ iknezevic@bfspc.bg.ac.rs
}

I. Knežević, University Textbooks of Theology: Lexical Features in Relation to Academic Theological Papers, Elpis, 23 2021: 55-62.

I. Knežević, Uniwersyteckie podręczniki teologiczne: charakterystyka leksykalna w odniesieniu do akademickich prac teologicznych, Elpis, 23 2021: 55-62

\begin{abstract}
The style characteristic of scientific works of theology differs greatly from the scientific style of other fields of science, but it also shows many common characteristics and similarities with them. The specific methodology of theology as well as the peculiarities of its scientific knowledge inevitably affect the extralinguistic and intralinguistic features of theological scientific works. The lexical layer of language is the most prominent representative of each field of science individually, and of the theology as well. This paper deals with the issue of the specific features of the linguistic level of university textbooks of theology. In the analysis of the mentioned problem the author has conducted and applied the results of the statistical analysis of the representative corpus of the university textbooks and academic works of theology, and, where possible and necessary, the contrastive analysis has been applied.

Streszczenie: Styl charakterystyczny dla prac naukowych z zakresu teologii w znacznym stopniu różni się od stylu naukowego innych dziedzin naukowych lecz można również zauważyć wiele wspólnych cech i podobieństw. Specyficzna metodologia z zakresu teologii i specyfika tego rodzaju wiedzy naukowej niewątpliwie wpływa na pozajęzykowe i wewnątrzjęzykowe cechy teologicznych prac naukowych. Warstwa leksykalna języka jest czołowym przedstawicielem każdej dziedziny nauki, w tym również teologii. W niniejszym artykule podjęto kwestię specyfiki poziomu językowego podręczników uniwersyteckich z zakresu teologii. W trakcie analizy wyżej przedstawionego problemu autorka przeprowadziła i zastosowała wyniki analizy statystycznej reprezentatywnego korpusu podręczników uniwersyteckich i naukowych prac z zakresu teologii, a tam, gdzie było to możliwe i konieczne, zastosowano również analizę kontrastową.
\end{abstract}

Keywords: university textbooks of theology, academic works of theology, scientific-educational substyle, functional stylisticstheolinguistics

Slowa kluczowe: uniwersyteckie podręczniki z zakresu teologii, akademickie prace teologiczne, naukowo-podręcznikowy podstyl, poziom leksykalny, teolingwistyka

\section{(c) (i) (2)}

\section{Introduction}

The problem of the scientific style in the field of theology is a field of functional stylistics which in English, even in fragments, has not been the subject of research both from the monolingual and from the contrastive point of view. The style that is characteristic of scientific works in the field of theology differs greatly from the scientific style of other fields of science, but it also shows many common characteristics and similarities with them. The basic extralinguistic features of theological expression that are identical with the features of the scientific style of other disciplines are precision, abstractness, logic and objectivity. However, the specific methodology of theology as well as the peculiarities of its scientific knowledge inevitably affect the extralinguistic and intralinguistic features of theological scientific works (cf. Knežević \& Ranković, 2015, pp. 46-58).

Theological scientific style is realized in three basic substyles: scientific proper (or academic), scientific-textbook (scientific-educational or didactic), and popular sci- entific, and in a number of genres, such as monographs, scientific articles, studies, discussions, dissertations, textbook literature, encyclopedias, lexicons, presentations in scientific discussions, scientific papers, academic lectures, seminar, final and graduate theses of students, popular scientific presentations and genres of popular scientific literature.

The works of the social sciences, and thus of theology, possess greater independence and universality in terms of stylistic features than is the case with works in the field of natural sciences. This uniqueness, the impossibility to unify, and perform a simple, definite, all-encompassing analysis and classification, is particularly noticeable in the sphere of vocabulary. The lexical layer of language is the most prominent representative of each field of science individually.

The specificity of the subject of research in theology itself, i.e. the fact that, in addition to science, it also covers the sphere of religion as a form of social consciousness, is most clearly expressed on the lexical level, which is the most visible indicator of this relationship between science 
and religion. Specific lexical elements are present in scientific theological works to a greater or lesser extent and depending on several factors, such as belonging to a certain scientific substyle, target readership, genre of a scientific text, basic subject of research of a given scientific work, individuality of the author, etc.

\section{The Study}

The starting point of our paper is the analysis and consideration of the lexical level of theological scientific papers, primarily scientific-textbook and scientific proper (academic) substyle.

For the purposes of this paper, we have then carried out a statistical analysis of the vocabulary of a representative corpus of scientific-textbook and academic papers in the field of theology in English, and performed a contrastive analysis of the obtained results. The analysis includes the following works of scientific-textbook substyle: The Church in the Ancient Society, Henry Chadwick; The Cambridge Companion to St Paul, D.G. Dunn; and An Introduction to the New Testament and the Origins of Christianity, Delbert Burkett; as well as works of scientific proper (academic) substyle: The New Testament: Introduction, Paul Nadim Tarazi; Of Water and the Spirit, Alexander Schmemann; and The Byzantine Legacy in the Orthodox Church, John Meyendorff.

Statistical analysis has been conducted on a corpus of a thousand words of each individual paper, in order to determine the percentage of general scientific and narrowly professional terminology separately and as a whole, as well as internationalisms and Church Slavonicisms. Based on the analysis, we have pointed out the differences at the lexical level between university textbooks of theology, on one hand, and academic theological papers, on the other. We have analyzed the vocabulary of each university textbook individually and represented it, emphasizing the specifics not only of the vocabulary in general, but also the specifics of each individual work where and if it was necessary. This was necessary both because of the nature of the theological science itself, and because of the subject of research, but also because of the individuality of the author expressed here.

Since the nature of scientific expression strives for precision and conciseness, the use of terminological apparatus is inevitable for science in general. Therefore, the important distinctive feature of science, that is, the one that distinguishes it from other areas of human activity, is the specific vocabulary, primarily terms. In all, even in theological scientific works within the terminology, two subgroups can be distinguished: general scientific terminology; and narrowly professional or nomenclatural terminology - terminology characteristic of a narrow field of science (here theology).

General scientific vocabulary is a common lexical apparatus of science in general. It indicates the connection of all sciences, and makes theology a member of this sphere of human activity which is of great importance for the entire human society, for its progress and development (economic, material, spiritual, etc.). These lexical means are an important distinctive feature of the scientific style, i.e. they clearly differentiate it in relation to other styles in which general scientific vocabulary is almost never used, or that is very rarely done, and then the terms get a different function (cf. Gumovskaâ, 2008, pp. 35-36). A large part of the general scientific vocabulary consists of internationalisms, which is especially the case with terms of Latin and Greek origin. For the purpose of science a large part of basic, common words is rather undefined, so they borrow words form Greek and Latin (Kristal, 1987, p. 380).These terms in English often retain their plural forms by transferring them from the language from which they originate (e.g. datum-data; analysis-analyses).

However, what forms the basis of every paper, even a scientific work, is not terms, but basic, common vocabulary words. They are dominant in the scientific text and represent the link between the language of science and the language of literature, journalism, administration, etc. that is, of the language as a means of communication that nurtures and maintains a strong connection of all members of the human community.

As in the common vocabulary words a large number of semantically neutral words have several meanings, in scientific papers there is a need to use the given words in only one or two probable (vocabulary, primary) meanings that they have in the general, standard language. Insisting on the precision of the theological text also affects the narrowing of polysemy. The semantic span is lost, but in the works of science it is not felt as scantiness or poverty of expression, but as a necessity without which the logical movement of thought would not be possible as well as the way to verbalize and convey it in an understandable way.

In addition, some of the words of general vocabulary in the language of science can acquire the character of terms, both of general scientific and narrowly professional, theological terms, e.g. (predestination, divine, paradise, sin, disciple, reveal) which in professional theological scientific work almost always have one specific meaning. The need for precise and unambiguous expression affects the narrowing of their meaning when they are used in the very framework of a scientific text.

The narrowing of the meaning of some commonly used lexemes in the language of theology is also indicated by the capital letter with which they are most often written (Cross, Church, Resurrection, the Father, the Son).

In the theological works of the scientific-textbook substyle, narrowly professional terms are not as numerous as is the case with the scientific works of the scientific proper substyle. This is understandable given the fact that the authors of scientific proper papers count on interlocutors equal to themselves, i.e. on a professional readership instructed in the meaning of the terms used, whom even their high frequency in the text does not obstruct in adopting information; on the contrary, it makes it easier since the terms carry precise, informatively saturated data. For the 
same reasons, the terms used in such scientific papers will not be further explained or defined, which is not the case with scientific-textbook (and far less with scientific popular) works.

Terms also appear in scientific papers in the form of phraseologisms, in other words, they are phraseological units of terminological character. According to their composition, they are phraseologisms of the syntagm type, multi-unit names of scientific concepts which in the scientific style are very often considered only multi-unit terms, not phraseologisms (Stanoǰčić \& Popović, 2008, p. 203). In the theological scientific literature, these are phraseologisms such as the original son, Holy Mysteries, the Holy Spirit, etc.

A significant part of the lexicon of theological works consists of internationalisms, words that are also found in various other languages in a more or less adapted form. By using internationalism instead of a native, mother-tongue equivalent, the author marks his work and himself as a member of the international scientific community, as important and separate in relation to other spheres of human activity.

Among internationalisms, there are not only general scientific terms, but, what is far more important for this paper, narrowly professional terminology. When it comes to narrowly professional terms, they are primarily derived from Latin and Greek, but also from Hebrew. They are adapted mainly by the transcription process or are phonologically and morphologically adapted in English. They mostly entered the English language during the Middle Ages and eventually became domesticated. The following are some of the examples from the corpus of the analyzed works with the data on their etymology according to the Word Origin dictionary:

Liturgy - Etymologically, liturgy means 'public performance'. It comes via late Latin līturgia from Greek leitourgíā 'public service or worship'

anathema-Originally in Greek anáthēma was a 'votive offering' (it was a derivative of the compound verb anatithénai 'set up, dedicate', formed from the prefix ana- 'up' and the verb tithénai 'place', source of English theme and related to English do)

Collins English Dictionary gives the etymology for the following terms:

exegesis-From Greek, from exēgeisthai "to interpret", from EX- hègeisthai "to guide" (1991, p. 542) hesychast-From Medieval Latin hesychasta mystic, form Greek hēsukhasets, form hēsukhazein, to be tranquil, from hēsukhos quiet. (1991:729) synod-From late Latin synodus, from Greek sunodos, from SYN- + hodos a way. (1991, p. 1564)

In addition, the theological nomenclature vocabulary includes a large number of words that are calques or loan translations (translated, either in part or in whole, to corresponding English words while still retaining the original meaning in English), most often from the original Greek form of the word. Thus, for example, the Birthgiver of God would be a translation of an originally Greek word, which is also found in theological scientific texts, primarily by Orthodox authors, in the transcribed form Theotokos. English dictionaries rarely record this form, while there is a far better known and generally accepted form Virgin Mary.

An important feature and a special layer of the lexicon of theological works are numerous Church Slavonicisms. They are not so frequent in papers in English and often appear depending on the origin of the author of the scientific paper in English (usually of Russian or Serbian origin), but also in connection with the substyle and subject of research.

The use of Church Slavonicisms in theological works, as well as internationalisms (Latinism, Grecism, Hebraism), either in transliterated or in a copied form of the original form, gives the scientific text a tone of seriousness, distance and uniqueness, and leaves the impression of "high style". Sometimes such copied forms of words or constructions are woven into the very fabric of a scientific text, with or without translation or with an explanation of the meaning in the further course of the text or in parentheses, and are present primarily in academic works.

Authors of all scientific papers, even theologians, in an effort to mark their works, emphasize their universality and separation from other segments of human activity, in addition to the use of terms-internationalisms, as markers of "high style" seldom use foreign words and expressions "copied", most often from the Latin language, in its original form - that is, in the form and alphabet of the given source language. These foreign words refer to: cliched phrases that are characteristic of scientific texts in general (ad hoc, de facto, etc.); and abbreviations - "auxiliary apparatus", for which almost every language has appropriate equivalents (e.g. ibid, et al, vs, etc.).

Apart from the mentioned cases, the authors of scientific papers often tend to use foreign language words even when it comes to terms - in the form of words, phrases, constructions, which are usually taken from the original source. This is often the case with those terms that are in a given form in a foreign language well known to scientists in the given field. However, these can also be newly created terms, which as such have not yet been adopted, recognized and accepted in a given scientific environment, and other authors, in case they mention them, have a need to give their original form in a given foreign language in addition to the translated form.

Besides, authors often cite entire constructions or sentences in a foreign language, with or without translation, which do not include terminological but also basic, everyday vocabulary. This is the case when quoting other people's thoughts, as well as original titles of some works. In this way, the authors demonstrate their erudition, competence for dealing with the problems of the given area, confirming their authority and trust with the reader.

Similar markers of "high style" are archaic forms of words present in theological scientific works, but Church 
Slavonicisms, especially those adapted phonologically and morphologically, can often be felt as archaisms. Church Slavonicisms are not the dominant and distinct feature of the lexicon of theological scientific works, and their appearance is usually conditioned by the individuality of the author of a given scientific work.

In theological scientific papers in English, there are archaic, obsolete forms of nouns (charger - a large platter; exchanger - money changer, banker), pronouns (thou, thee, thy, thine), adjectives (meet - appropriate, suitable, fitting; untoward - perverse, intractable, crooked), adverbs (aforehand - beforehand; annon - immediately, at once), verbs (adjure - to bind by oath or solemnly entreat; assay - to attempt, try), as well as verb-endings from Middle English (hath, art, knowest) (Ricks), and they are almost always a part of the content of the Holy Scripture which is quoted in a given scientific work with a certain intention.

Abstractness is another feature of the vocabulary of all scientific and also of theological works. The tendency of science to express knowledge generally influences the fact that abstract vocabulary, both terminological and basic, is far more represented in scientific works than concrete. This is even further supported by the very nature of the subject of research and interest of theology.

In addition, in the field of science, authors get the opportunity to express their creativity when it comes to creating new words - neologisms or coinages. As Crystal notes, science is an especially productive field for new coinages (Kristal, 1987, p. 380). Terms can appear as coinages - newly created lexical forms for naming certain terms in science. The author is obliged to define them when he uses them for the first time if he is their creator, and then they can be generally accepted, adopted in a given scientific field and eventually come to life as independent terms. Some of them, which do not resonate with the scientific audience, will end their lives as neologisms. The field of theology, in contrast to the vast majority of other scientific spheres, gives opportunities to the author-expert to express individuality and creative abilities not only when it comes to terms but also the "connective tissue", basic vocabulary as a carrier of expression. For some authors, this word creativity in particular becomes recognizable as a personal stamp, bringing the style of even scientific proper papers in close connection with the belles-letters style, without damaging the expression itself in terms of ambiguity, inaccuracy, or obscurity.

Every presentation, even a theological one, which pretends to be scientific, imposes an obligation on the author to use one very important tool. Namely, out of the need to point out the logical sequence of thoughts and organize a complex exposition, theological texts, as well as texts of other sciences, resort to „auxiliary means“, i.e. words that have the function of organizing the presentation. For that purpose, various conjunctions, adverbs, introductory words and syntagms, phrases, impersonal and indefinite sentences are used. Their functions are numerous, and express different relationships between the facts and the arguments presented by the author. In the examined cor- pus of scientific papers, they are especially numerous and diverse (i.g. thus, moreover, nevertheless, on the one...on the other hand, first of all, finally).

Insisting on the precision of the theological text, in addition to narrowing the polysemy, also affects the frequent repetition of the same words, that is, the uniformity and stinginess of the scientific vocabulary, which is not perceived here as the roughness of style and poverty of language. Moreover, this is an expected and necessary property of scientific expression so that the reader's attention would not diffuse and be lost in the search for the meaning of the expression, but in order to focus on the essence of the text - the information that the author seeks to present.

In the case of repetition, the professional term cannot be replaced by another with a similar meaning, or descriptively transferred without losing its exactness. In addition, the frequent appearance of the same term will not be perceived by the reader (listener) as stylistically inappropriate, nor sound vexing. Their repetition does not make the scientific style less valuable, nor is it perceived as a disadvantage. On the contrary, the use of a small number of words, both professional and from basis, common vocabulary, can make it easier for the reader to "master the content of the text", i.e. to monitor and receive (new) information.

\section{Methodology}

Based on the statistical analysis of the corpus of scientific proper and scientific-textbook works in the field of theology in English, the following results have been obtained.

In university textbooks in English, general scientific terms make up on average about $7 \%$ of the total lexical fund, more precisely in The Church in the Ancient Society they make up about 7\%, in An Introduction to the New Testament and the Origins of Christianity about $5 \%$, while in The Cambridge Companion to St Paul 10\%. In the corpus of analyzed works of scientific proper substyle, general scientific terms are represented almost uniformly, and make up about $11 \%$ of the total lexical fund. More precisely, in The New Testament: An Introduction they make up about $10 \%$ of the total vocabulary, in The Byzantine Legacy in the Orthodox Church 11\%, and in Of Water and the Spirit about $12 \%$. Thus, in comparison with the share of general scientific vocabulary in works of scientific proper substyle $(11 \%)$, in the works of scientific-textbook substyle, this share has been reduced by about $4 \%$.

Narrowly professional terms in the corpus of university textbooks in English also make up on average about $9 \%$ of the total lexical fund - in The Church in the Ancient Society they make up about 6\%, in An Introduction to the New Testament and the Origins of Christianity about 16\%, while in The Cambridge Companion to St Paul about 5\%. Of the examined corpus of scientific proper substyle in English, narrowly professional terms make up 7-11\%, which on average is about $9 \%$ - in The New Testament: An Introduction they make up about $9 \%$ of the total vocab- 
ulary, in The Byzantine Legacy in the Orthodox Church $7 \%$, and in Of Water and the Spirit about $11 \%$. The share of narrowly professional terms in the works of university-textbook and scientific proper substyle is therefore equal $(9 \%)$.

The total percentage of general and narrowly professional terms in university textbooks in relation to the total vocabulary is on average about $16 \%$, more precisely in The Church in the Ancient Society about 13\%, in An Introduction to the New Testament and the Origins of Christianity about 21\%, while at The Cambridge Companion to St Paul $15 \%$. The total representation of terms, both general and narrowly professional, in relation to the entire vocabulary in academic papers is on average about $20 \%$ - in The New Testament: An Introduction about 18\%, in The Byzantine Legacy in the Orthodox Church 18\%, and in Of Water and the Spirit about 23\%. The difference in relation to the use of the total number of narrowly professional and general scientific terms between the scientific-textbook and scientific proper substyle is about $4 \%$.

This difference in the use of terms is visible not only when it comes to their frequency, but also the way they are used. In the works of the scientific proper substyle, the professional term itself is most often used without definitions, except in cases of original or non-traditional use. In contrast, professional terms, primarily narrowly professional, in university textbooks, when mentioned for the first time, are usually accompanied by a definition, explanation or detailed description, in accordance with the goals and objectives of the scientific course or textbook. Once explained, it can then appear more than once in the same text. Such nomenclature terms in textbooks are often accompanied by etymological data, with forms from foreign language given in parentheses from which they originated and their possible original, primary meaning. Sometimes they require extended presentations about possible changes in their meaning throughout history or in different environments, etc. The author of such scientific papers becomes a linguist himself, and refers to etymology in order to achieve certain didactic goals.

Within narrowly professional terms, university-textbook authors prefer to use internationalisms (Grecisms, Latinisms and Hebraism) which make up an average of $29 \%$ of the total fund of narrowly professional vocabulary (or about $2.6 \%$ of the total lexical fund), in The Church in the Ancient Society about 34\%, in An Introduction to the New Testament and the Origins of Christianity about 28\%, while in The Cambridge Companion to St Paul $27 \%$. Of the total fund of narrowly professional terms, the average of internationalisms in academic papers is about $12 \%$ (or 1\% of the total lexical fund): in The New Testament: An Introduction they make up about $6 \%$ of the total narrowly professional vocabulary ( $0.5 \%$ of the total lexical fund), in The Byzantine Legacy in the Orthodox Church $12 \%$ (1\% of the total lexical fund), and in Of Water and the Spirit about $18 \%$ ( $2 \%$ of the total lexical fund).

However, the authors of the examined corpus of works of both scientific proper and scientific-textbook substyle are not inclined to use Church Slavonicisms in narrowly professional terminology, so they are completely absent in the given corpus of works.

\section{Discussion}

The high frequency of internationalisms in the total share of narrowly professional terminology in the examined textbook corpus can be explained by the fact that these are university textbooks of theological. The authors had in mind that the target readership consists of future experts, who are on the verge of becoming full members of a group of experts in the given field, and who already have a high level of knowledge in the field. On the other hand, the analysis also shows that it is a case of the repetition of the same nomenclature internationalisms, which also affects their number. Unlike scientific proper papers, where the author has no need of repetition, in textbooks the repetition of the same terms is necessary and expected for a more detailed explanation, so the sentences are shorter making the presentation more accessible. Moreover, a term once used and explained if necessary, makes the author free to use it further in the text without fear of causing confusion among readers. In addition, repetition in the university textbooks is not considered a disadvantage, but is common and expected by the target audience. Thus, e.g. in the examined part of the corpus (of 1000 words) in Introduction to the New Testament internationalism-noun Gentiles and adjective Gentile (Hebraism, according to Collins English Dictionary: from 4th century, from Late Latin gentilis, from Latin: one belonging to the same tribe or family (644)) appear as many as 17 and 15 times, respectively; and apostles as many as 6 times.

Important markers of a scientific text, foreign words by which we primarily mean "obsolete" phrases, but also abbreviations, most often from the Latin language, will seldom appear in textbook texts. We have rare examples of abbreviations in the English corpus, e.g. in Introduction to the New Testament:

In Luke 8:19-21, Jesus identifies his true family not as those who are physically related to him (i.e. the Jews), but as all who hear and do his word. (Burkett, 2002, p. 264)

We rarely find an example of a phrase in a foreign, Latin language, additionally separated from the rest of the text, either given in parenthesis or in italics, such as:

The archdeacon thought this brawling in church and rebuked her; she went off in a huff (irata discessit) (Chadwick, 2003, p. 54).

It is par exellence a gift of leadership (Dunn, 2003, p. 81).

Foreign words, primarily nomenclature terms, which are transliterated into English, or used in their original form, i.e. in the alphabet of the original language (in the- 
ology most often from Greek, Latin or Church Slavonic), appear less often in textbooks than is the case with professional scientific papers. They almost never appear on their own, without explanation, because the author cannot expect the target audience to be acquainted with their meaning, particularly when it comes to textbooks in the field of theology. The author does not have a reader-expert equal to himself, so having that in mind, he does not use the words that the reader will not be able to understand, or that will divert his attention from the basic idea. Foreign words, as we mentioned earlier, can appear next to the appropriate nomenclature term in English, definition, or other type of explanation, and functioning as additional information in brackets, or, less often, vice versa. The authors of the analyzed corpus in English did this in the following ways. In The Church in the Ancient Society we have:

At first they bore the simple title 'deacon'; the female 'deaconess' (diakónissa) is a later form (Chadwick, 2003, p. 54).

It was also called the Thanksgiving; in the Didache, Ignatius, and Justin this word is already technical: eucharistia.

A consequence of this in the past has been the feeling among the clergy that so sacred a text as the central eucharistic prayer of consecration and offering, in Latin the 'canon of the mass', in Greek 'anaphora', should be mumbled, not said aloud, because it has mystery at its heart (Chadwick, 2003, p. 212).

The author translates these foreign words by transliteration into English from the Greek language, separating the given word either in italics or placing it under quotation marks. He cannot expect the readership to be able to read the given words in the original alphabet (here in the Greek alphabet), so in this way he brings them closer to the original form. The meaning of these words is previously explained in the sentence, or in the text, and this form appears as a kind of additional information, which the recipient, as necessary or at least desirable, should in the author's opinion adopt.

Similarly to this in The Introduction to the New Testament we have the following examples:

In Acts 5:11, Luke refers to this community of believers as the "church" (Greek ekklesia, "assembly"), the translation of a term used in the Hebrew Scriptures to designate the "congregation" or "assembly" of God's people (Burkett, 2002, p. 270).

In parentheses, the author provides the origin, the transliterated form (of an originally Greek term) separated by italics, as well as the meaning in the given original language, and gives the word itself outside the brackets, dealing, according to the purpose of the textbook, with the etymology of the same term.

In The Cambridge Companion to St Paul, words of foreign origin (Greek, Latin, Hebrew and German) are highlighted in italics in the text, and their meaning can be found in the Glossary at the beginning of the paper, or is given in the text before or after the given word. Here are the following examples:

There has rarely been much doubt about the principal letters (Hauptbriefe) - Romans, 1 and 2 Corinthians and Galatians (Dunn, 2003, p. 3).

In common with many other (particularly American) scholars, Martyn reinforces the christocentric character of Paul's gospel by advocating Paul's talk of 'faith' in his key polemical discussion on the theme is a reference not to human trust (pistis Christou $=$ 'faith in Christ') but to the faithfulness of Christ ( $p i-$ stis Christou = 'faith of Christ') (Dunn, 2003, p. 12). The main idea in Paul's mind seems to have been his commission to missionary work in universal dimensions, i.e. to permeate with the gospel what his contemporaries considered the 'Western world' and liked to talk of as 'inhabited world' (oikumene), that is, the Mediterranean world under Roman rule (Dunn, 2003, p. 28).

What is true of Paul as 'ambassador' is true also of Paul as 'apostle' (apostolos), the much more frequent self-designation (Gal. 1:1; 1 Cor. 1:1; Rom. 1:1) (Dunn, 2003, p. 36).

He and Apollos are both 'servants' (diakonoi) of God and 'fellow workers' (sunergoi) in relation to each other (Dunn, 2003, p. 37).

The message Paul preached ('our gospel' - 1:15) to these Macedonians was a narrative of 'good news' (euaggelion) which he characterized variously as 'the gospel of God' $(1: 5 ; 2: 2,8,9)$ and 'the gospel of Christ' (3:2) (Dunn, 2003, p. 52).

Once explained, they may appear later in the text, also in italics, such as:

Well into the twentieth century, indeed, the key question was when 'old Catholicism' or 'early Catholicism' (Frühkatholizismus) first emerged (Dunn, 2003, p. 4).

And further on in the text:

And on the other, the Frühkatholizismus issue has been restated in terms provided from the sociology of Max Weber (Dunn, 2003, p. 5).

Here are some more examples:

This was the belief that the human condition was one of imprisonment and ignorance, the spirit within ('sparks o light') needing to be enlightened, given knowledge (gnosis) as to its true nature and origin. In the myth, salvation is brought by the 'light-person' who enters this lower world to bring the saving, lifegiving gnosis (Dunn, 2003, p. 8).

It is hardly to be denied, of course, that Paul sha- 
red with his environment language and concept like 'knowledge' (gnosis) and 'spiritual' (pneumatikos) (Dunn, 2003, p. 9).

The use of foreign words, in addition to the Greek language and the Greek alphabet, which are woven into the fabric of the text without translation and explanation, is still an extremely rare occurrence in university textbooks.

Neologisms are also a rarity in textbooks. Authors of university textbooks do not have the freedom as authors of scientific proper papers. The form and scope of scientific information is dictated by the scientific program, and the system of presentation and proof must be adjusted to the level of prior knowledge and the age of the recipient. Therefore, in the scientific-textbook substyle, there is no such creative freedom, both when it comes to forging new expressions, and the use of expressive means of language (stylistic figures), which is possible in scientific proper works. Communication between the author-expert and a potential future expert can be difficult or even impossible if the author of the textbook violates these restrictions, which would call into question the validity of the same textbook as a didactic tool. We have a rare case in The Cambridge Companion to St Paul, where the author creates a new word, but by derivation and from English elements, so the meaning can be easily understood:

To a limited practical extent the incoming Judaizers were 'Corinthianized'_and the local Spirit-people 'Judaized' (Dunn, 2003, p. 84).

Or it is a compound of also familiar elements from English:

Martyn reinforces the christocentric character of Paul's gospel by advocating Paul's talk of 'faith' in his key polemical discussions (Dunn, 2003, p. 12).

The entire lexical fund must be adjusted to the level of knowledge of the target readership. In this regard, the narrowing of polysemy remains a necessary feature of textbook texts, in order to facilitate the reception of information. The used words always have one, specific meaning in the textbook scientific text, and not more (either figurative or secondary meanings). Thus e.g. in The Church in the Ancient Society we have the word tradition which has several meanings (Collins English Dictionary records as many as seven), but in theological texts it is always used in the meaning (given under number 4) Christianity - a doctrine or body of doctrines regarded as having been established by Christ of the apostles though not contained in Scripture. This corresponds to the only definition of this noun offered by The Concise Dictionary of the Christian Church (The Concise Dictionary of the Christian Church, 2000, p. 585). While the word disciple has two meanings (according to Collins English Dictionary), in theological texts only one meaning is always implied, here it is the second of the following:

\section{disciple, noun}

1. a follower of the doctrines of a teacher or a school of thought.

2. one of the personal followers of Christ (including his 12 apostles) during his earthly life.

Jesus of Nazareth, a charismatic prophet from Galilee, gathered to himself a community of disciples to help in a reform of the Jewish religious tradition, which looked back to the Hebrew prophets and their expectation of divine intervention. (Collins English Dictionary, 1991, p. 5).

We also find only one, narrow meaning of this term in The Concise Oxford Dictionary of the Christian Church:

Disciples, the. A term sometimes used of the12 Apostles whose names are recorded in the Gospels (The Concise Dictionary of the Christian Church, 2000, p. 170).

The repetition of the same words is a feature of the scientific-textbook, as well as of the academic substyle. Even in textbooks, repetition does not feel like a stylistic irregularity, but rather as a rule and a necessity. The abundance of synonyms would not correctly and accurately convey information when it comes to terms. The richness of vocabulary (which is a feature primarily of belles-lettres style) would make it difficult to perceive information, and the primary goal of the textbook would not be achieved.

We have singled out some interesting examples from the analyzed corpus, e.g. in The Cambridge Companion to St Paul:

Love is the greatest of all the gifts because it is totally dedicated to the good of the other (Ch. 13). It is what makes Christians Christlike. Paul singles out one expression of love for special mention, the gift of prophecy (14:1-25). It is par excellence a gift of leadership. It is the gift which most builds up, directs, and sustains the community (14:3) (Dunn, 2003, p. 22).

Here, the term gift is irreplaceable in its narrow meaning (= gift from God), and a synonym should not be used so as not to confuse the reader by leading him to think that it is another term.

Words as organizers of the presentation (conjunctions, conjunction words, adverbs, introductory words and syntagms, phrases, impersonal and indefinite sentences) are present in smaller numbers and are less diverse. The system of proving and presenting knowledge must be adapted to the target audience. The author of textbooks avoids long, complex constructions and sentences whose meaning can hardly be followed by the reader of the textbook. As the author of a textbook should not only convey information, but also do so in such a way that the reader can easily understand and adopt it, he must take care to present his thoughts in a clear and understandable way. This is often neglected by the authors of some textbooks, creating textbooks that 
lose their didactic value due to the pretentious motives of the authors themselves or their "inability" to adapt to the intellectual level and prior knowledge of the readership to who they address. The example of these words in textbooks is small, they are quite uniform and are often repeated several times.

\section{Conclusion}

The works of the scientific-textbook substyle differ in the goal, content and character of the target readership from the works of the scientific proper substyle. Namely, the character of the addressee - prior knowledge, motivation and needs, will influence the style of texts of the scientific-textbook substyle, which will be reflected on all three language levels (lexical, morphological and syntactic), and the most obvious influence will be on the lexical level. The specificity of theology as a science will particularly impact the lexical level of theological scientific works.

The addressees of texts of a scientific proper substyle are primarily experts specialized in a given scientific field, who are at the highest level familiar with the issue, so academic papers are the most saturated with content and information of all other scientific substyles and are characterized by increased use of terms. Unlike them, the addressees of the scientific-textbook substyle are young people, future experts who have a desire for knowledge in a given field, as well as the already formed motivation for improvement. Based on all the above, we can conclude that the vocabulary of university textbooks differs somewhat from the vocabulary of academic papers, especially when we consider the use of general scientific vocabulary and the total share of terms, while the use of narrowly professional terms is identical, and the use of internationalisms-terms in the corpus of the selected university textbooks is higher in relation to their use in academic papers.

Repetition of words and narrowing of polysemy remains an important feature of university textbooks, while phrases in a foreign (Latin) language, foreign words as a nomenclature term and words that have the function of organizing a presentation are less frequent. However, despite these differences, we do not notice extreme differences at the lexical level between academic papers and university textbooks. The reason for this is the fact that the addressees of university textbooks have a dose of seriousness and are ready to receive and adopt the transmitted information, with the potential aspiration to become one day a part of a narrow circle of experts in a given field of science. However, this will not be the case when it comes to the addressee of (primary or secondary) school textbooks, which should be the subject of an analysis of a some new paper, since it opens the possibility of comparison the scientific-textbook substyle with regard to a specific target readership, i.e. university and (primary or secondary) school audience.

\section{Bibliography}

Ayto, J. (2005). Dictionary of Word Origins. London: A\&C Black. [online] https://epdf.pub/word-origins3614fb1227e6bc6639 5f8df79e544a3691633.html, [19.09.2020]

Burkett, D. (2002). An Introduction to the New Testament and the Origins of Christianity. Cambridge: Cambridge University Press.

Chadwick, H. (2003). The Church in the Ancient Society: From Galilee to Gregory the Great. Oxford: Oxford University Press.

Collins English Dictionary. (1991). Glasgow: HarperCollins Publishers.

Concise Oxford Dictionary of the Christian Church. (2000). Oxford: Oxford University Press.

Dunn, J. D. G. (2003). The Cambridge Companion to St Paul. Cambridge: Cambridge University Press.

Gumovskaâ, G. (2008). LSP: English for Professional Communication: Anglijskij âzyk professional'nogo obŝeniâ. Moskva: Aspekt Press.
Knežević, I. i Ranković, Z. (2015). Naučni stil i žanrovi naučnih radova u oblasti teologije. Komunikacija i kultura online, 6. Beograd. 46-58. https://www.komunikacijaikultura.org/index.php/kk/article/view/63

Kristal, D. (1987). Kembrička enciklopedija jezika. Beograd: Nolit. Meyendorff, J. (1982). The Byzantine Legacy in the Orthodox Church. New York: St Vladimir's Seminary Press.

Schmemann, A. (1974). Of Water and the Spirit. New York: St Vladimir's Seminary Press.

Stanoǰić, Ž. i Popović, L̂. (2008). Gramatika srpskog jezika. Beograd: Zavod za ud̂benike.

Ricks, E. A Short Glossary of Obsolete Words in the King James New Testament [online]

https://www.churchofjesuschrist.org/study/new-era/1977/04/a-short-glossary-of-obsolete-words-in-the-king-jamesnew-testament?lang=eng, [27.09.2020]

Tarazi, P. N. (1999). The New Testament: An Introduction. New York: St Vladimir's Seminary Press. 